\title{
Enhancing oxygen reduction electrocatalysis through tuning crystal structure: Influence of intermetallic MPt nanocrystals
}

\author{
Jiashun Liang, Zhengpei Miao, Feng Ma, Ran Pan, Xian Chen, Tanyuan Wang, Huan Xie, Qing Li * \\ School of Materials Science and Engineering, Huazhong University of Science and Technology, Wuhan 430074, Hubei, China
}

\section{A R T I C L E I N F O}

\section{Article history:}

Received 29 November 2017

Accepted 23 December 2017

Published 5 April 2018

\section{Keywords:}

Electrocatalysis

Oxygen reduction reaction

Nanocrystal

Intermetallics

Alloy

\begin{abstract}
A B S T R A C T
The slow kinetics of oxygen reduction reaction (ORR) occurring at the cathode of a proton exchange membrane fuel cell require the presence of an electrocatalyst to reduce overpotential. MPt alloy nanocrystals (NCs) have been investigated over the last decade as efficient catalysts for ORR and recent studies have shown that structurally-ordered MPt NCs, i.e., intermetallic NCs (iNCs), are more active and exhibit enhanced stability compared with the corresponding randomly alloyed analogues. This mini-review highlights the recent progress in iNC catalyst development for ORR with emphasis on correlating the synthesis-structure-activity relationship. Perspectives and possible research directions to enhance MPt iNC catalytic performance are also proposed.
\end{abstract}

(C) 2018, Dalian Institute of Chemical Physics, Chinese Academy of Sciences. Published by Elsevier B.V. All rights reserved.

\section{Introduction}

Proton exchange membrane fuel cells (PEMFCs) are widely recognized as promising renewable energy sources that can play a role in overcoming the current global energy crisis and address environmental concerns. In practice, oxygen reduction reaction (ORR), which occur at the PEMFC cathode are often limited by high activation barriers, and hence require the presence of an electrocatalyst, which severely hinders PEMFC commercialization [1,2]. There has been great progress in the development of non-precious metal ORR catalysts [3-5], and carbon-supported Pt catalysts, which hitherto remain the-state-of-the-art ORR catalysts. However, their use is strictly limited by the prohibitive cost and that further improvements to activity/stability are required [6-10]. Nørskov et al. [11] reported that during ORR, the Pt-oxygenated species interaction was very strong, and thus, hindered reactant product desorption. In principle, the binding strength, which is directly related to the $d$-band center position of Pt catalysts, can be tuned by introducing a second metal, in which the bimetallic alloy results in changes to the Pt electronic state, and concomitantly its interaction. Based on this paradigm, a wealth of interdependent research has focused on developing MPt $(\mathrm{M}=\mathrm{Fe}$, $\mathrm{Co}, \mathrm{Cu}, \mathrm{Ni}$, etc.) catalysts [12-15]. However, these MPt nanocrystals (NCs) are often in a solid-solution structure because of the existing diffusion barrier. In PEMFCs, which operate in acid environments, the $M$ is subject to etching, leaving a low-coordinated Pt surface and structural integrity loss of the NCs.

There are cases where MPt alloys can convert into intermetallic structures according to thermodynamic principles. Compared with disordered alloys, the atoms in intermetallic NCs (iNCs) arrange alternately and interact strongly because of the $3 d-5 d$ orbital interactions between $\mathrm{M}$ and $\mathrm{Pt}$, thereby preventing transition metal etching. Furthermore, iNCs provide predictable control over structural, geometric, and electronic ef-

\footnotetext{
*Corresponding author. Tel: +86-18707120529; Fax: +86-27-87546587; E-mail: qing_li@hust.edu.cn

This work was supported by the National 1000 Young Talents Program of China, the National Natural Science Foundation of China (21603078), and National Materials Genome Project (2016YFB0700600).

DOI: 10.1016/S1872-2067(17)62989-9 | http://www.sciencedirect.com/science/journal/18722067 | Chin. J. Catal., Vol. 39, No. 4, April 2018
} 
fects, which allows rationale MPt catalyst design with enhanced performance. In theory, the formation of the intermetallic structure is rather complicated in having multiple influencing variables such as composition, electronegativity, and electron density. The Gibbs free energy of intermetallic $\left(G_{\text {intermetallic }}\right)$ and disordered ( $G_{\text {disorder}}$ ) structures can be employed to evaluate the thermodynamic stability of a binary system and mapped onto a phase diagram. If $G_{\text {intermetallic }}$ of an MPt alloy is smaller than $G_{\text {disorder }}$ at the working temperature, such an MPt system could be converted into an intermetallic phase through external energy inputs (e.g., temperature and pressure) [16].

MPt iNCs were first explored for ORR in fuel cells in 1994 [17]. Typically, MPt iNCs can be prepared via thermal annealing of disordered NCs above the phase transformation temperature, which can be found from their phase diagrams. However, as a result of the difficulties in synthesizing monodisperse and uniform iNCs without particle agglomeration during high-temperature annealing, only a very limited number of MPt iNCs have been successfully prepared $[7,18,19]$. In this mini-review, we highlight the representative examples of MPt iNCs, i.e., FePt, CoPt, and PbPt, and correlate composition and morphology to catalytic performance.

\section{FePt iNCs}

According to the theory put forward by Nørskov, alloying Pt with a late transition metal can lower the $d$-band center, and thus decrease the bonding energy resulting in improved activity. The theory is also an effective approach to reduce Pt usage. FePt iNCs have been widely investigated as magnetic materials for data storage and high performance magnets [20,21]. With exact compositional control (Fe/Pt atomic ratio should be $\sim 1 / 1$ according to the phase diagram), the face-centered cubic (fcc) or L10-FePt can be converted to a chemically-ordered intermetallic structure, denoted as face-centered tetragonal (fct) FePt. Recent studies have proven that these ordered fct-FePt NCs can be used as active and stable catalysts towards ORR [22]. Sun et al. [22] prepared $\sim 8 \mathrm{~nm}$ disordered fcc-FePt polyhedral NCs by the controlled decomposition of iron pentacarbonyl (Fe(CO) 5 ) and reduction of platinum acetylacetonate ( $\left.\mathrm{Pt}(\mathrm{acac})_{2}\right)$ (Fig. 1(a)). After supporting on carbon, the nanoparticles (NPs) were annealed at $650{ }^{\circ} \mathrm{C}$ for $1 \mathrm{~h}$, and the disordered fcc structure was converted to an ordered fct structure, in which $\mathrm{Fe}$ and $\mathrm{Pt}$ stacked alternately along the $c$-direction (Fig. 1(b)). After electrochemical dealloying, a FePt/Pt core/shell structure having a $\sim 0.6 \mathrm{~nm}$ Pt shell was confirmed by scanning transmission electron microscopy-electron energy loss spectroscopy (STEM-EELS) line scans (Fig. 1(c)). ORR polarization curves revealed that the intermetallic NCs exhibited greater activity than the corresponding disordered analogues (Fig. 1(d)). Density functional theory (DFT) calculations indicated that the $\mathrm{Pt}-\mathrm{O}$ binding energies $\left(\Delta E_{0}\right)$ of fct-FePt is $0.23 \mathrm{eV}$, smaller than that of fcc-FePt $(0.26 \mathrm{eV})$ and closer to the optimal $\Delta E_{0}(0.2 \mathrm{eV})$. The change in $\Delta E_{0}$ may originate from the compressed surface strain. When fcc-FePt transforms to fct-FePt in the core, the surface strain of Pt was smaller, and thus reduced $\Delta E_{0}$ and promoted ORR activity. (a)

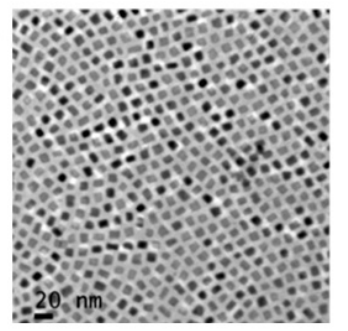

(b)

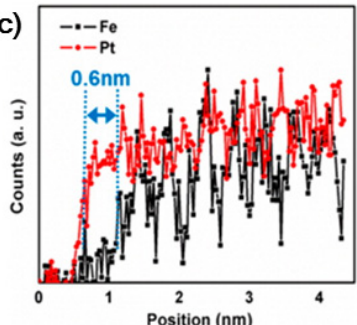

(d)
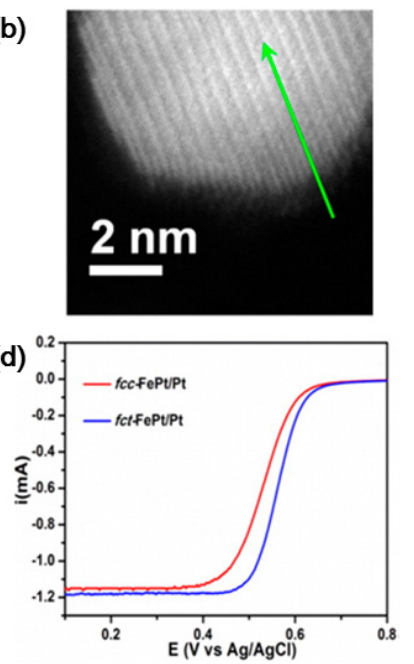

Fig. 1. (a) Transmission electron microscopy (TEM) image of the as-synthesized fcc $\mathrm{Fe}_{51} \mathrm{Pt}_{49}$ NPs. (b) High angle annular dark field-scanning transmission electron microscopy (HAADF-STEM) image (c) STEM-electron energy loss spectroscopy (EELS) line scan of an electrochemically dealloyed $\mathrm{C}$-fct $\mathrm{Fe}_{51} \mathrm{Pt}_{49} \mathrm{NP}$, forming C-fct-FePt/Pt. The arrow in the HAADF-STEM micrograph indicates the line scan position. (d) ORR polarization curves of fcc- and fct-FePt/Pt. The ORR polarization curves were obtained in $\mathrm{O}_{2}$-saturated $0.1 \mathrm{~mol} \mathrm{~L}^{-1} \mathrm{HClO}_{4}$ with the working disk electrode rotating at $1600 \mathrm{r} \mathrm{min}^{-1}$ and a potential scan rate at $10 \mathrm{mV} \mathrm{s}^{-1}$. Reprinted with permission from Ref. [22], copyright American Chemical Society, 2014.

However, one drawback in this case, is that the Pt/Fe atom mobility is strictly confined to the polyhedral precursor structure, resulting in partially-ordered NCs. Recently, we circumvented this problem by using dumbbell-like fcc-FePt- $\mathrm{Fe}_{3} \mathrm{O}_{4}$ as a precursor to achieve full crystal ordering in monodispersed 8.8 nm fct-FePt NPs (Fig. 2(a), (b)) [7]. In this approach, the $\mathrm{Fe}_{3} \mathrm{O}_{4}$ comprising the dumbbell-like $\mathrm{FePt}-\mathrm{Fe}_{3} \mathrm{O}_{4}$ (Fig. 2(b)) structure, can be reduced to Fe during gas annealing, which creates defects upon $\mathrm{O}$ removal (from $\mathrm{Fe}_{3} \mathrm{O}_{4}$ ) and facilitates $\mathrm{Fe}$ and $\mathrm{Pt}$ reorganization into the fully-ordered fct-FePt (Fig. 2(a)). Magnetic measurements show the fully-ordered fct-FePt NC hysteresis loop to have a single-phase loop with the coercivity reaching $33 \mathrm{kOe}$, indicating the presence of a perfect L10-ordered structure. Compared with the partially-ordered FePt, disordered FePt, and commercial Pt/C, the fully-ordered FePt NPs exhibit the highest $E_{1 / 2}$ (Fig. 2(c)) and excellent stability in $0.1 \mathrm{~mol} \mathrm{~L}^{-1} \mathrm{HClO}_{4}$ (Fig. 2(d)). The stable structure of the fct-FePt NPs is confirmed by high angle annular dark field-STEM (HAADF-STEM) imaging after 20,000 potential cycles under acidic conditions. The Fe/Pt ordering is clearly indicated by the high $(\mathrm{Pt})$ and low $(\mathrm{Fe}) \mathrm{Z}$ contrast (Fig. 2(e)), providing evidence that the fct structure is well maintained after potential cycling. Importantly, the composition exhibited negligible change after potential cycling (Fe/Pt: 44/56), indicating the stability of Fe in fct iNCs, even when subjected to acid.

Besides the degree of crystal ordering, another challenge that should be addressed is the MPt iNC size, which is larger than $8 \mathrm{~nm}$ in the majority of the reported studies, and results in lower mass activity and increases cost. Relative utilization of $\mathrm{Pt}$ 
and surface area availability of NC catalysts can be significantly enhanced by reducing the NC size. Wang et al. [23] have successfully synthesized 3-4 nm FePt NCs by the galvanic replacement between $\mathrm{Fe}$ and $\mathrm{Pt}^{4+}$ embedded in a carbon matrix (Fig. 3(a)). After annealing, an fct-FePt iNC structure was obtained with well-defined ordering, as clearly indicated by the high $(\mathrm{Pt})$ and low $(\mathrm{Fe}) \mathrm{Z}$ contrast in the STEM image (Fig. 3(b)). The protection afforded by the amorphous carbon matrix prevented severe aggregation of the FePt NPs during annealing at $900{ }^{\circ} \mathrm{C}$ (Fig. 3(c)). Compared with the aforementioned FePt iNCs, particle size was significantly smaller ( $3.6 \mathrm{vs.} 8.8 \mathrm{~nm}$ ), and the measured mass activity was enhanced by a factor of 7.4 relative to the commercial Pt/C catalyst (Fig. 3(d)). A recent study has reported a new approach to synthesize iNC/carbon core/shell catalysts [13]. In this work, FePt iNCs were coated with $\mathrm{N}$-doped carbon shells derived from polydopamine and the obtained catalysts exhibited enhanced activity and good stability. However, in this case, there is difficulty to identify the real active sites and how FePt influences activity.

\section{CoPt iNCs}

Similar to FePt, Co is also a transition metal that can improve activity, or as a result of highly optimized tuning of the $d$-band center, can improve $\Delta E_{0}$ over that of FePt [11]. According to the phase diagram, CoPt can also be converted into iNCs when subjected to appropriate treatment, such as annealing at $700{ }^{\circ} \mathrm{C}$. The influence of how the CoPt system orders with respect to ORR catalysis has been investigated at the very early stages [17]. However, results show that the ordered CoPt NPs suffer from severe activity loss, compared with only $1 \%$ activity loss in the corresponding disordered alloys. Recently, the ordering transformation of $\mathrm{Pt}_{3} \mathrm{Co}$ iNCs, which were synthesized using an impregnation-reduction method, demonstrated new (a)

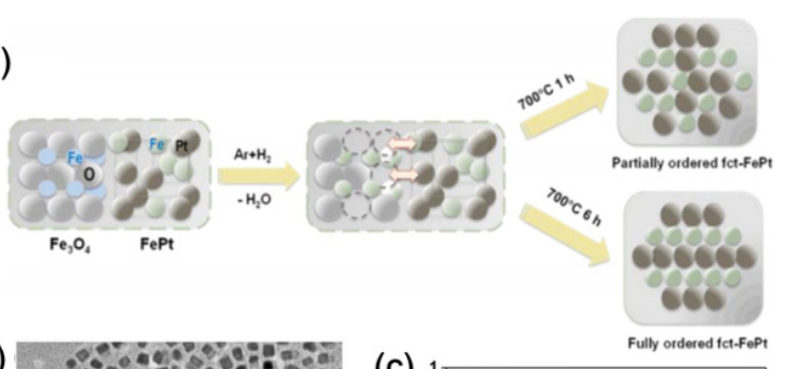

(b)
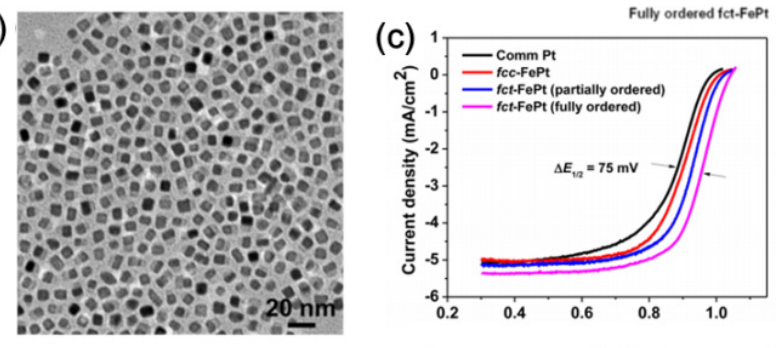

(d)
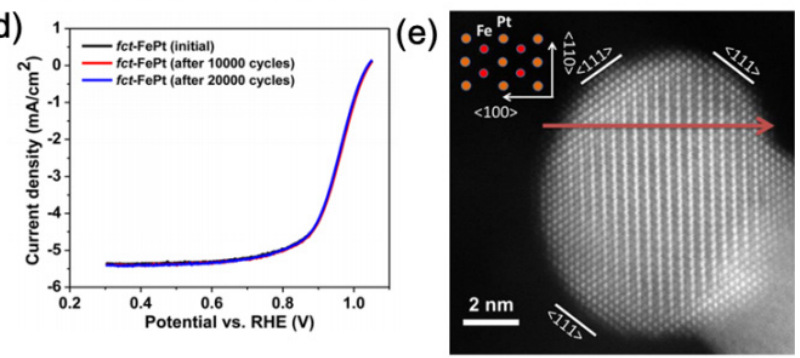

Fig. 2. (a) Schematic illustration of the formation of $\mathrm{L} 1_{0}$-FePt NPs via reductive annealing of dumbbell $\mathrm{FePt}-\mathrm{Fe}_{3} \mathrm{O}_{4}$ embedded in an $\mathrm{MgO}$ matrix. (b) TEM micrograph of the as-prepared dumbbell-like $\mathrm{FePt}_{-} \mathrm{Fe}_{3} \mathrm{O}_{4}$ NPs. (c) ORR polarization curves of C-Pt, C-fcc-FePt, partially- and fully-ordered C-fct-FePt NPs in $0.1 \mathrm{~mol} \mathrm{~L}^{-1} \mathrm{HClO}_{4}$ (rotating speed $1600 \mathrm{r}$ $\mathrm{min}^{-1}$, scan rate $10 \mathrm{mV} \mathrm{s}^{-1}$ ). (d) ORR polarization curves of the fully-ordered fct-FePt NPs before and after potential scans between 0.6 and $1.0 \mathrm{~V}$. (e) HAADF-STEM image of a representative fully-ordered L1 10 -FePt NP after 20,000 potential cycles. Reprinted with permission from Ref. [7], copyright American Chemical Society, 2015.

(a)
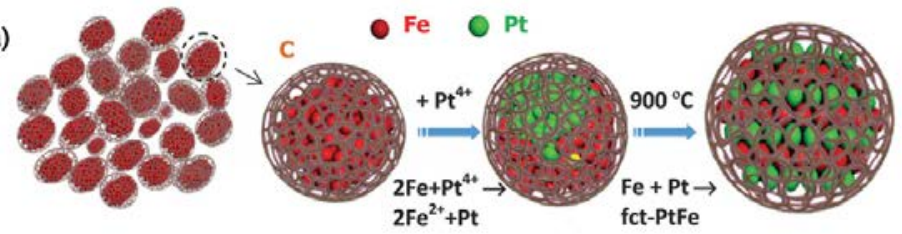

(b)
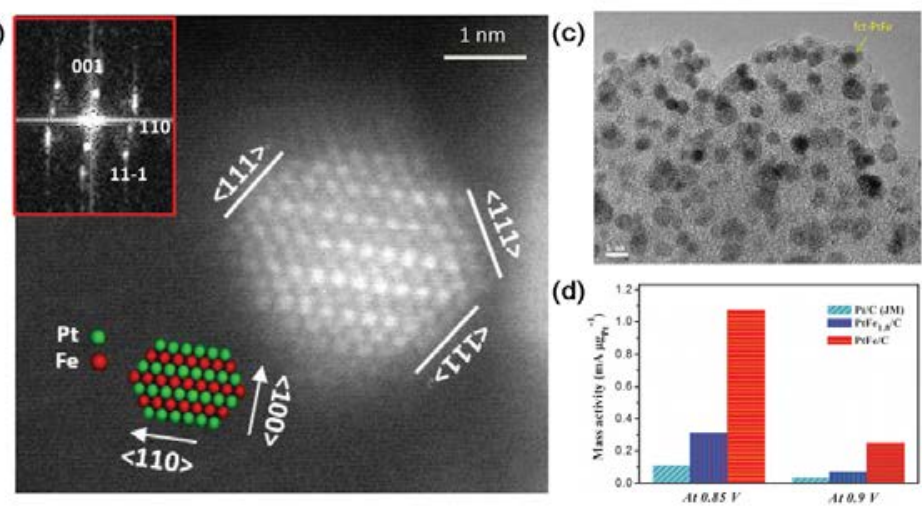

Fig. 3. (a) Schematic illustration of the formation of L10-FePt NPs embedded in a carbon matrix. (b) Aberration-corrected STEM micrograph of a FePt particle (inset: fast Fourier transformation pattern). (c) Fine FePt particles entrapped in the carbon matrix after heat treatment. (d) Comparison of mass activity at 0.85 and $0.9 \mathrm{~V}$ for FePt/C, FePt1.8/C, and Pt/C catalysts in $0.1 \mathrm{~mol} \mathrm{~L}^{-1} \mathrm{HClO}_{4}$ (rotating speed $1600 \mathrm{r} \mathrm{min}^{-1}$, scan rate $10 \mathrm{mV} \mathrm{s}^{-1}$ ). Reprinted with permission from Ref. [23], copyright Royal Society of Chemistry, 2015. 
results by annealing $\mathrm{H}_{2} \mathrm{PtCl}_{6} \cdot \mathrm{H}_{2} \mathrm{O}, \mathrm{CoCl}_{2} \cdot 6 \mathrm{H}_{2} \mathrm{O}$ and carbon at 700 ${ }^{\circ} \mathrm{C}$ for $2 \mathrm{~h}$ [18]. Owing to the unique super periods that are not present in the disordered alloy phase, the presence of the L12-ordered intermetallic structure in $\mathrm{Pt}_{3} \mathrm{Co}$ can be directly identified from atomic-resolution ADF-STEM imaging (Fig. 4(a)). Unlike the aforementioned L10 structure, the projected $\mathrm{L} 1_{2}$ unit cell is composed of a periodic square array of pure Co columns surrounded by $\mathrm{Pt}$ atoms along the [001] axis. Among $\mathrm{Pt} / \mathrm{C}, \mathrm{Pt}_{3} \mathrm{Co} / \mathrm{C}-400$ and $\mathrm{Pt}_{3} \mathrm{Co} / \mathrm{C}-700$, the latter showed a marked positive shift in ORR $E_{1 / 2}$ of $\sim 70 \mathrm{mV}$ relative to $\mathrm{Pt} / \mathrm{C}$ (Fig. 4(b)). Furthermore, $\mathrm{Pt}_{3} \mathrm{Co} / \mathrm{C}-700$ displayed higher mass activity (Fig. 4(c)) and enhanced stability after potential cycling compared with the corresponding disordered analogue (Fig. 4(d)). However, it should be noted that it is difficult to evaluate the degree of crystal ordering in this work.

Another strategy to enhance ORR electrocatalysis is to develop one-dimensional (1D) nanowires (NWs). NWs provide a higher surface area that interacts with the carbon support compared with NCs. This advantage not only enhances electron transfer between oxygen and the catalyst surface, but also facilitates bonding between the NWs and the carbon support, thus achieving high structural stability and electro-conductivity. However, high-temperature annealing often destroys the NW structure, yielding spherical nanoparticles. Huang et al. [24] circumvented the issue of NW structural integrity loss by employing a seed-mediated method. They reported the synthesis of crenel-like $\mathrm{Pt}_{3}$ Co hierarchical NWs with an $\mathrm{L}_{2}$ intermetallic structure, high-index facets, and a Pt-rich surface in oleylamine (OAm) at $160{ }^{\circ} \mathrm{C}$ for $8 \mathrm{~h}$ (Fig. 5(a)). In this reaction, glucose served as a reducing agent to first reduce Pt and subsequently Co, with cetyltrimethylammonium chloride (CTAC) acting as the structure-directing agent. The presence of the two agents resulted in the formation of $2 \mathrm{~nm}$ Pt NWs. Thereafter, the newly-reduced Co species diffused into the Pt NWs. After aging for (a)
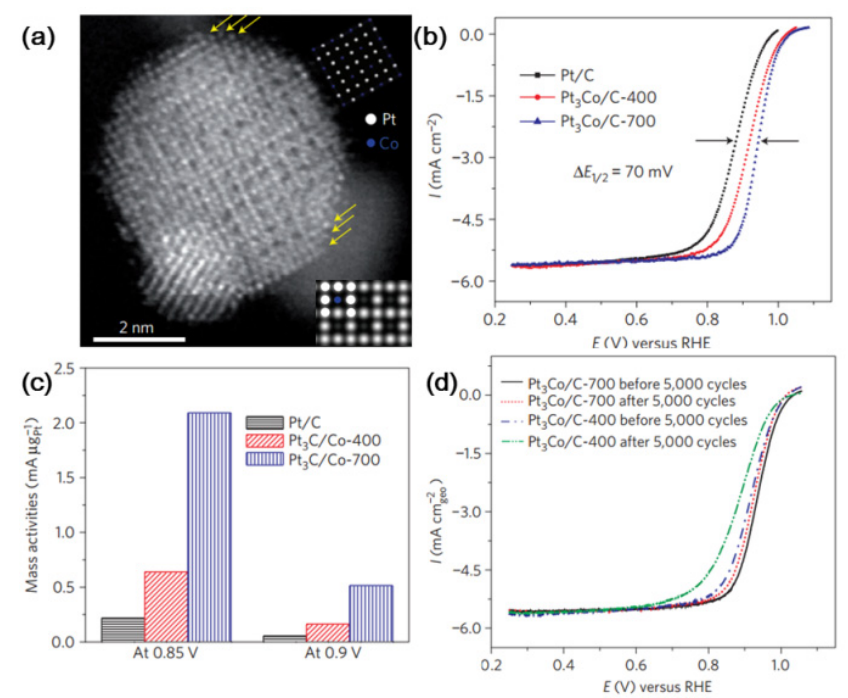

Fig. 4. (a) Atomic-resolution ADF-STEM micrograph of $\mathrm{Pt}_{3} \mathrm{Co} / \mathrm{C}-700$ (inset: the simulated ADF-STEM image of $\mathrm{L}_{2}$-ordered $\mathrm{Pt}_{3} \mathrm{Co}$ along [001]). (b) ORR polarization curves for $\mathrm{Pt} / \mathrm{C}, \mathrm{Pt}_{3} \mathrm{Co} / \mathrm{C}-400$ and $\mathrm{Pt}_{3} \mathrm{Co} / \mathrm{C}-700$ in $0.1 \mathrm{~mol} \mathrm{~L}^{-1} \mathrm{HClO}_{4}$, (rotating speed, $1600 \mathrm{r} \mathrm{min}^{-1}$; scan rate, $10 \mathrm{mV} \mathrm{s}^{-1}$ ). (c) Comparison of mass activity for $\mathrm{Pt} / \mathrm{C}, \mathrm{Pt}_{3} \mathrm{Co} / \mathrm{C}-400$ and $\mathrm{Pt}_{3} \mathrm{Co} / \mathrm{C}-700$ at 0.85 and $0.9 \mathrm{~V}$. (d) ORR polarization curves for $\mathrm{Pt}_{3} \mathrm{Co} / \mathrm{C}-400$ and $\mathrm{Pt}_{3} \mathrm{Co} / \mathrm{C}-700$ in $0.1 \mathrm{~mol} \mathrm{~L}^{-1} \mathrm{HClO}_{4}$ after 5,000 potential cycles. Reprinted with permission from Ref. [18], copyright Nature Publishing Group, 2013.

$8 \mathrm{~h}$, intermetallic structures were formed and the ordering of $\mathrm{Pt}$ and Co can be identified by HAADF-STEM imaging (Fig. 5(b)). With respect to ORR testing, $\mathrm{Pt}_{3}$ Co exhibited a specific activity of $7.12 \mathrm{~mA} \mathrm{~cm}^{-2}$ and a mass activity of $3.71 \mathrm{~A} \mathrm{mgPt}^{-1}$ at $0.9 \mathrm{~V}$ (Fig. 5(c)). The catalyst exhibits good ORR stability after long-term cycling without sacrificing ORR activity (Fig. 5(d)). This excellent stability is thought to be attributed to the $1 \mathrm{D}$ morphology and the intermetallic structure.

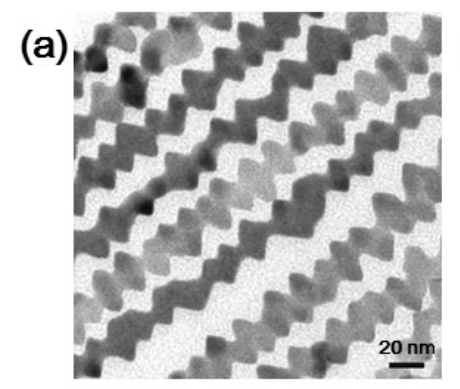

(b)
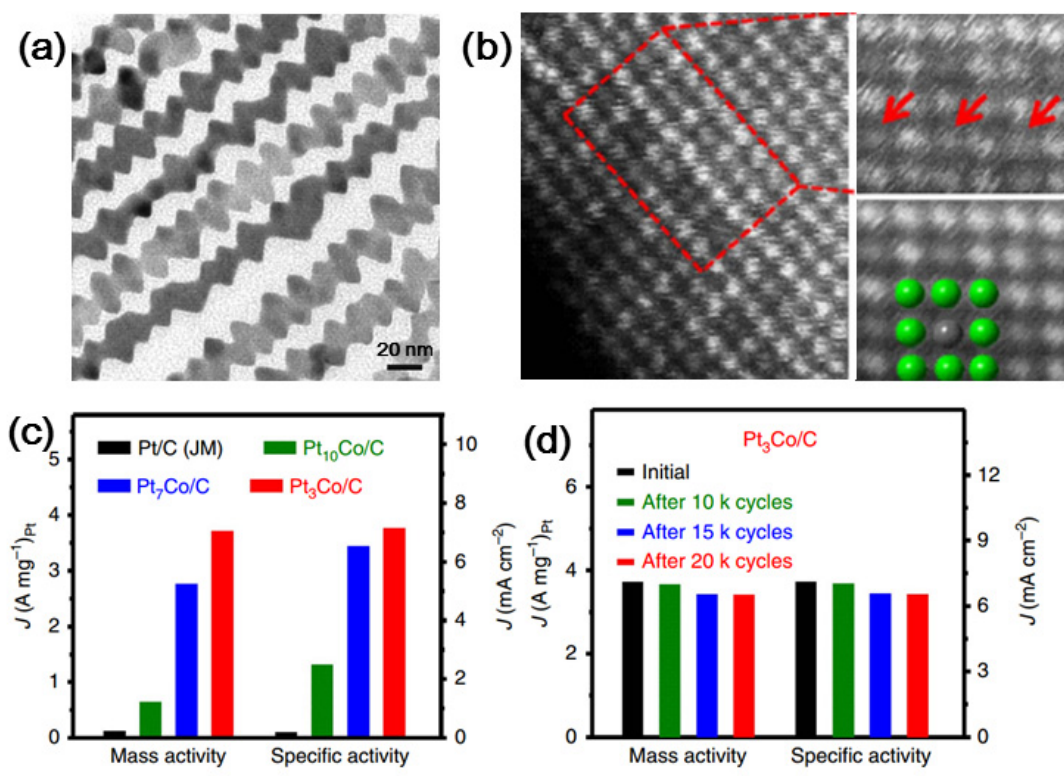

Fig. 5. (a) TEM micrograph of $\mathrm{Pt}_{3}$ Co nanowires (NWs). (b) Atomic-resolution HAADF-STEM images of Pt ${ }_{3}$ Co NWs. (c) Mass activity and specific activity as a function of catalyst type at $0.9 \mathrm{~V}$. (d) Mass activity and specific activity of $\mathrm{Pt}_{3} \mathrm{Co} / \mathrm{C}$ at $0.9 \mathrm{~V}$ after potential cycling. Reprinted with permission from Ref. [24], copyright Nature Publishing Group, 2016. 


\section{PbPt iNCs}

Controlling surface strain is an alternative strategy to tune the Pt $d$-band structure and thus optimize the catalysis. As a result of the lattice mismatch between the surface Pt shell and the core, the surface Pt is usually under a strained state. According to theoretical calculations, it is widely accepted that subjecting the Pt surface to an appropriate compressed strain can improve catalytic activity [25]. Because a $\mathrm{Pb}$ atom is larger than a Pt atom, tensile strain would result in a PbPt system and is usually disadvantageous for the catalyst.

However, a recent report by Huang et al. [19] presented unconventional results by applying biaxial strain to intermetallic B8 ${ }_{1} \mathrm{PbPt}$ nanoplates, in which $7.5 \%$ tensile strain along the [001] direction and compressed strain along the [110] direction were induced. In the synthesis, ascorbic acid (AA) was used as a weak reducing agent, which was key for NC growth into core/shell nanoplates (Fig. 6(a)). Unlike the aforementioned iNCs, in which high-temperature annealing was required, the transformation temperature is relatively low (160 ${ }^{\circ} \mathrm{C}$ ). The ordered core/shell structures are clearly identified by HAADF-STEM imaging (Fig. 6(b)). The degree of strain was controlled in a different direction as a result of the ordering of the structure, and therefore, systematic illustration was feasible. DFT calculations suggest that an appropriate tensile strain along the [001] direction can weaken the bonding energy between Pt and $O$ at the (110) facets, and thus increase catalytic
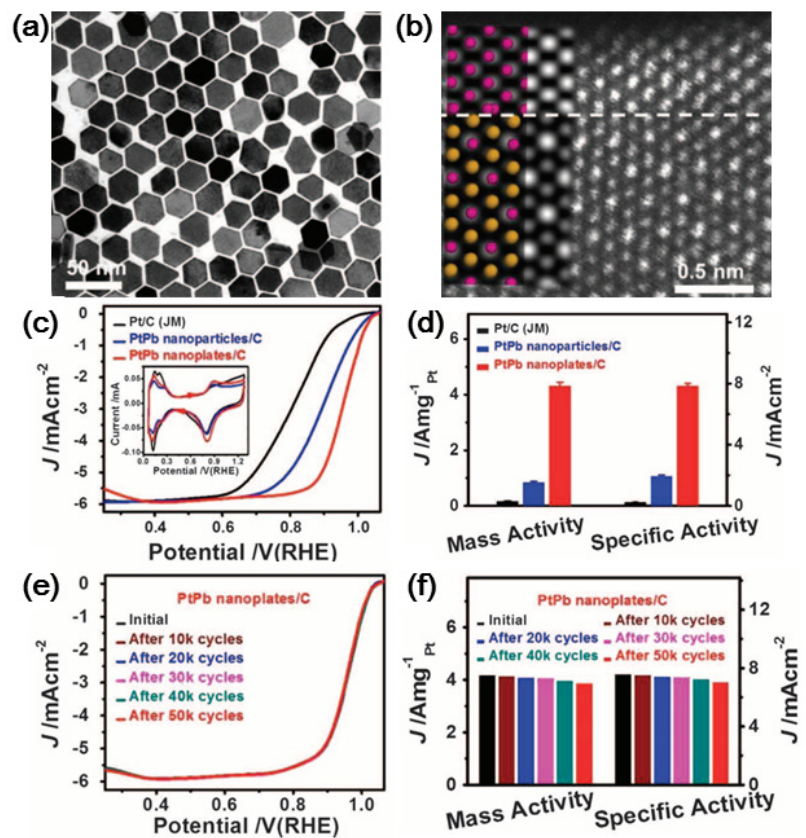

Fig. 6. (a) TEM image of PbPt nanoplates. (b) HAADF-STEM image of $\mathrm{PbPt}$ nanoplates. (c) ORR polarization curves recorded at room temperature in an $\mathrm{O}_{2}$-saturated $0.1 \mathrm{~mol} \mathrm{~L}^{-1} \mathrm{HClO}_{4}$ aqueous solution (rotating speed $1600 \mathrm{r} \mathrm{min}^{-1}$, scan rate $10 \mathrm{mV} \mathrm{s}^{-1}$ ). (d) Mass activity and specific activity as a function of catalyst type at $0.9 \mathrm{~V}$. (e) ORR polarization curves of the $\mathrm{PbPt}$ nanoplates/C catalyst before and after potential cycling between 0.6 and $1.1 \mathrm{~V}$ vs. reversible hydrogen electrode (RHE). (f) Mass activity and specific activity of PbPt nanoplates/C at $0.9 \mathrm{~V}$ after potential cycling. Reprinted with permission from Ref. [19], copyright American Association for the Advancement of Science (AAAS), 2016. activity. As a result, $\mathrm{PbPt}$ nanoplates/C exhibited the highest catalytic activity among $\mathrm{Pt} / \mathrm{C}, \mathrm{PbPt} \mathrm{NPs} / \mathrm{C}$ and $\mathrm{PbPt}$ nanoplates/C, with a specific activity and mass activity of $7.8 \mathrm{~mA}$ $\mathrm{cm}^{-2}$ and $4.3 \mathrm{~A} \mathrm{mg}_{\mathrm{Pt}^{-1}}{ }^{-1}$ at $0.9 \mathrm{~V}$, respectively (Fig. 6(c), (d)). After 50,000 sweeping cycles, there was only a $7.7 \%$ loss of mass activity for the PbPt nanoplates (Fig. 6(e), (f)).

In a later report, Huang et al. [26] reported morphological changes from plate to $\mathrm{PbPt}$ octahedra simply by reducing the presence of AA (Fig. 7(a)). Because the PtNi(111) facet is suggested to be highly active for ORR [12,27-30], a PbPt/NiPt core/shell structure with a thin NiPt shell was obtained (Fig. 7(b)). Combining the collective benefits of intermetallic structures, the NiPt shell, with induced tensile strain along [001] direction, the catalysis was greatly improved. Further increasing $\mathrm{Ni}$ doping resulted in further improvements to the activity and the $\mathrm{PbPt}_{1.12} \mathrm{Ni}_{0.14}$ octahedra/C showed the highest activity with a specific activity and mass activity of $5.16 \mathrm{~mA} \mathrm{~cm}^{-2}$ and $1.92 \mathrm{~A} \mathrm{mgPt}^{-1}$ at $0.9 \mathrm{~V}$, respectively (Fig. 7(c)). Both PbPt and $\mathrm{PtPb}_{1.12} \mathrm{Ni}_{0.14}$ octahedra/C were relatively stable. However, $\mathrm{PtPb}_{1.12} \mathrm{Ni}_{0.14}$ octahedra/C displayed enhanced stability compared with $\mathrm{PbPt}$, with less activity loss after potential cycling (Fig. 7(d), (e)).

\section{Summary and perspectives}

Intermetallic NCs are receiving ever-increasing attention in electrocatalysis. The iNCs adopt well-defined structure and composition that allow for NC catalyst rationale design. Compared with randomly alloyed NCs, MPt iNCs, e.g., FePt, CoPt, $\mathrm{PbPt}$, exhibit superior ORR catalytic activity because of their optimal $\Delta E_{0}$ at the Pt surface. Because ORR performance of intermetallic MPt catalysts is dependent on numerous factors, including the composition, size and shape of the iNCs, it is still too early to draw the conclusion of which transition metal would best enhance activity and stability after alloying with Pt. Furthermore, the strong interaction between Pt and M in the intermetallic structure helps to stabilize $\mathrm{M}$, and hinders etching when subjected to acids, thus improving long-term stability. However, intermetallic catalyst development is still at an early stage and there remains several challengers to be addressed. Generally, high temperatures are required to overcome the diffusion barrier to produce iNCs. However, such treatment can also destroy the NC morphology, and therefore, controlling the NC shape is difficult, with the majority of scientific studies reporting nanosphere iNC systems. Heading forward, there is a great opportunity to develop new methodologies, through thermodynamic and kinetic control, to better design shape control during the synthesis of intermetallic crystals. Conversely, reducing particle size is a promising approach to improve mass activity, in addition to reducing Pt usage. MPt iNCs typically possess particle sizes $>6 \mathrm{~nm}$, as a result of the challenges to prevent particle agglomeration in sub-5 nm NCs and the ease of phase transformations. Additionally, the reported majority of iNCs remain partially-ordered, which seriously impacts their inherent performance, and therefore, advanced synthetic strategies toward fully-ordered iNCs of various size, composition, and shape are highly desirable. It is of great fun- 
(a)

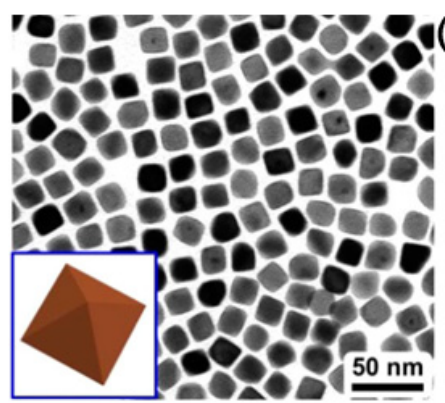

b)

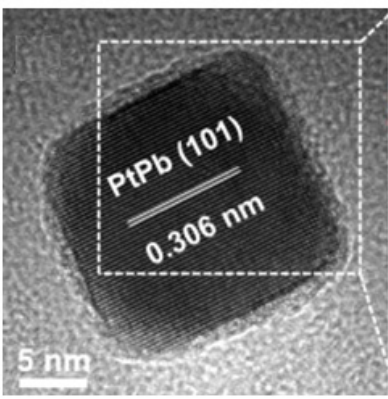

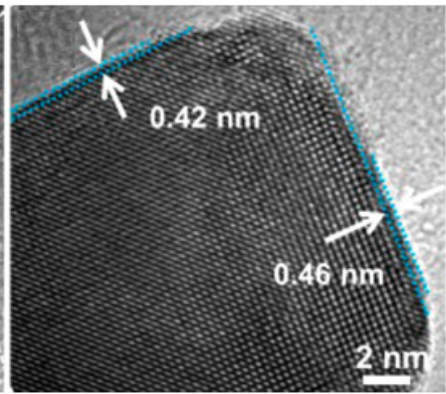

(e)

(d)

(c)

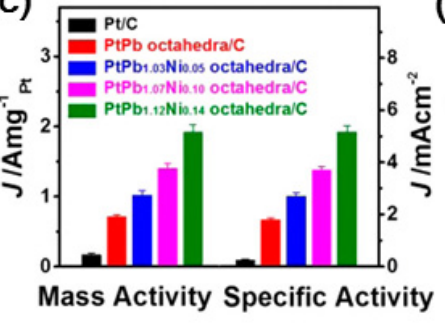

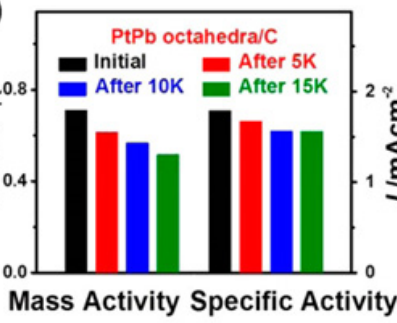

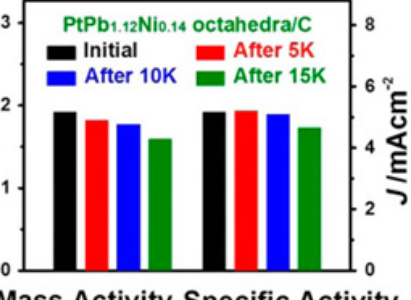

Fig. 7. (a) TEM micrograph of PbPt octahedra. (b) High resolution TEM image of PbPt/NiPt octahedra. (c) Mass activity and specific activity as a function of catalyst type at $0.9 \mathrm{~V}$. (d) Mass activity and specific activity of PbPt octahedra/C at $0.9 \mathrm{~V}$ after potential cycling. (e) Mass activity and specific activity of $\mathrm{PtPb}_{1.12} \mathrm{Ni}_{0.14}$ octahedral/C at $0.9 \mathrm{~V}$ after potential cycling. Reprinted with permission from Ref. [26], copyright American Chemical Society, 2017.

damental and practical significance to continuously investigate this new class of electrocatalysts to improve on the delicate structural features, and concomitantly, the catalytic activity.

\section{References}

[1] H. A. Gasteiger, N. M. Markovic, Science, 2009, 324, 48-49.

[2] M. K. Debe, Nature, 2012, 486, 43-51.

[3] Q. Li, G. Wu, D. A. Cullen, K. L. More, N. H. Mack, H. T. Chung, P. Zelenay, ACS Catal., 2014, 4, 3193-3200.

[4] Q. Li, T. Y. Wang, J. T. Han, D. Havas, H. G. Zhang, G. Wu, P. Xu, J. Cho, Adv. Sci. 2016, 3, 1600140.

[5] Q. Li, P. Xu, W. Gao, S. G. Ma, G. Q. Zhang, R. G. Cao, J. Cho, H. L. Wang, G. Wu, Adv. Mater., 2014, 26, 1378-1386.

[6] N. C. Cheng, M. N. Banis, J. Liu, A. Riese, X. Li, R. Y. Li, S. Y. Ye, S. Knights, X. L. Sun, Adv. Mater., 2015, 27, 277-281.

[7] Q. Li, L. H. Wu, G. Wu, D. Su, H. F. Lv, S. Zhang, W. L. Zhu, A. Casimir, H. Y. Zhu, A. Mendoza-Garcia, S. H. Sun, Nano Lett., 2015, 15,
2468-2473.

[8] Q. Li, S. H. Sun, Nano Energy, 2016, 29, 178-197.

[9] Y. Nie, L. Li, Z. D. Wei, Chem. Soc. Rev., 2015, 44, 2168-2201.

[10] Y. J. Wang, N. N. Zhao, B. Z. Fang, H. Li, X. T. Bi, H. J. Wang, Chem. Rev., 2015, 115, 3433-3467.

[11] V. R. Stamenkovic, B. S. Mun, K. J. J. Mayrhofer, P. N. Ross, N. M. Markovic, J. Rossmeisl, J. Greeley, J. K. Norskov, Angew. Chem. Int. Ed., 2006, 45, 2897-2901.

[12] V. R. Stamenkovic, B. Fowler, B. S. Mun, G. F. Wang, P. N. Ross, C. A. Lucas, N. M. Markovic, Science, 2007, 315, 493-497.

[13] D. Y. Chung, S. W. Jun, G. Yoon, S. G. Kwon, D. Y. Shin, P. Seo, J. M. Yoo, H. Shin, Y. H. Chung, H. Kim, B. S. Mun, K. S. Lee, N. S. Lee, S. J. Yoo, D. H. Lim, K. Kang, Y. E. Sung, T. Hyeon, J. Am. Chem. Soc., 2015, 137, 15478-15485.

[14] S. J. Guo, D. G. Li, H. Y. Zhu, S. Zhang, N. M. Markovic, V. R. Stamenkovic, S. H. Sun, Angew. Chem. Int. Ed., 2013, 52, 3465-3468.

[15] Y. J. Li, F. X. Quan, E. B. Zhu, L. Chen, Y. Huang, C. F. Chen, Nano Res., 2015, 8, 3342-3352.

\section{Graphical Abstract}

Chin. J. Catal., 2018, 39: 583-589 doi: 10.1016/S1872-2067(17)62989-9

Enhancing oxygen reduction electrocatalysis through tuning crystal structure: Influence of intermetallic MPt nanocrystals

Jiashun Liang, Zhengpei Miao, Feng Ma, Ran Pan, Xian Chen, Tanyuan Wang, Huan Xie, Qing Li *

Huazhong University of Science and Technology

This mini-review presents the recent development of intermetallic MPt NC catalysts for ORR focusing on how the intermetallic MPt structure/morphology relationship influences activity/stability. Current research challenges and future research perspectives are summarized and proposed.
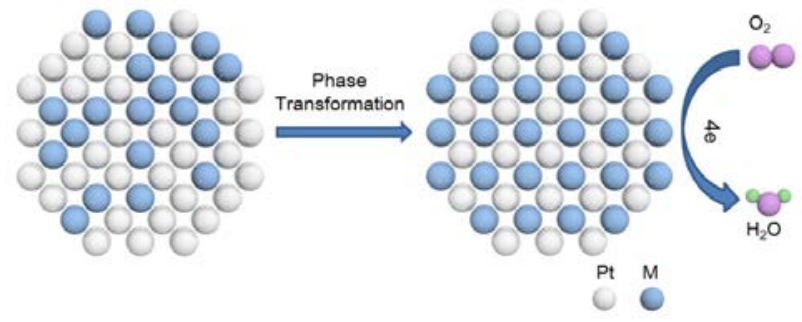
[16] Y. C. Yan, J. S. S. Du, K. D. Gilroy, D. R. Yang, Y. N. Xia, H. Zhang, $A d v$. Mater., 2017, 29, 1605997.

[17] M. Watanabe, K. Tsurumi, T. Mizukami, T. Nakamura, P. Stonehart, J. Electrochem. Soc., 1994, 141, 2659-2668.

[18] D. L. Wang, H. L. Xin, R. Hovden, H. S. Wang, Y. C. Yu, D. A. Muller, F. J. DiSalvo, H. D. Abruna, Nat. Mater., 2013, 12, 81-87.

[19] L. Z. Bu, N. Zhang, S. J. Guo, X. Zhang, J. Li, J. L. Yao, T. Wu, G. Lu, J. Y. Ma, D. Su, X. Q. Huang, Science, 2016, 354, 1410-1414.

[20] S. H. Sun, C. B. Murray, D. Weller, L. Folks, A. Moser, Science, 2000, 287, 1989-1992.

[21] J. Kim, C. Rong, J. P. Liu, S. H. Sun, Adv. Mater., 2009, 21, 906-909.

[22] S. Zhang, X. Zhang, G. M. Jiang, H. Y. Zhu, S. J. Guo, D. Su, G. Lu, S. H. Sun, J. Am. Chem. Soc., 2014, 136, 7734-7739.

[23] X. X. Du, Y. He, X. X. Wang, J. N. Wang, Energy Environ. Sci., 2016, 9, 2623-2632.

[24] L. Z. Bu, S. J. Guo, X. Zhang, X. Shen, D. Su, G. Lu, X. Zhu, J. L. Yao, J.
Guo, X. Q. Huang, Nat. Commun., 2016, 7, 11850.

[25] P. Strasser, S. Koh, T. Anniyev, J. Greeley, K. More, C.F. Yu, Z.C. Liu, S. Kaya, D. Nordlund, H. Ogasawara, M. F. Toney, A. Nilsson, Nat. Chem., 2010, 2, 454-460.

[26] L. Z. Bu, Q. Shao, B. E, J. Guo, J. L. Yao, X. Q. Huang, J. Am. Chem. Soc., 2017, 139, 9576-9582.

[27] L. Gan, C. H. Cui, M. Heggen, F. Dionigi, S. Rudi, P. Strasser, Science, 2014, 346, 1502-1506.

[28] X. Q. Huang, Z. P. Zhao, L. Cao, Y. Chen, E. B. Zhu, Z. Y. Lin, M. F. Li, A. M. Yan, A. Zettl, Y. M. Wang, X. F. Duan, T. Mueller, Y. Huang, Science, 2015, 348, 1230-1234.

[29] G. D. Niu, M. Zhou, X. Yang, J. Park, N. Lu, J. G. Wang, M. J. Kim, L. D. Wang, Y. N. Xia, Nano Lett., 2016, 16, 3850-3857.

[30] V. Beermann, M. Gocyla, E. Willinger, S. Rudi, M. Heggen, R. E. Dunin-orkowski, M. G. Willinger, P. Strasser, Nano Lett., 2016, 16, 1719-1725.

\title{
通过调控晶体结构提高氧气还原反应电催化活性: MPt金属间相纳米晶
}

\author{
梁嘉顺, 苗政培, 马 峰, 潘 然, 陈 仙, 王谭源, 谢 欢, 李 箐* \\ 华中科技大学材料科学与工程学院, 湖北武汉 430074
}

摘要: 燃料电池的正极主要发生氧还原反应(ORR), 但是该反应的动力学速率较慢, 需要催化剂来降低反应的过电势. 目 前商用的催化剂是碳载铂纳米粒子催化剂, 但是铂高昂的价格严重阻碍了燃料电池的大规模商业化. 近年来的理论和实 验研究表明, 过渡金属 $(\mathrm{M})$ 与铂 $(\mathrm{Pt})$ 形成的纳米晶合金 $(\mathrm{MPt})$ 能够作为有效的 ORR催化剂, 同时由于引入价格低廉的过渡金 属, 催化剂成本有所降低. 然而, 即使合金化的催化剂具有良好的初始催化性能, 但是在燃料电池的实际操作环境, 即高电 压、高温和酸性条件, 长时间运行之后, 过渡金属很容易被腐蚀流失, 从而留下表面配位数较低的铂原子, 而这些铂原子对 ORR反应几乎没有催化作用, 导致催化剂逐渐失活, 燃料电池的输出功率逐渐降低. 最近一些研究表明, 铂基催化剂在一 定条件下, 例如加热, 能够发生固态相变, 形成结构有序的即金属间纳米晶(iNCs). 与无序排列的合金相比, 这种有序的MPt 能够调控表面铂原子与含氧中间体的结合能, 可以进一步提高ORR活性; 同时, 由于在金属间纳米晶中铂原子与过渡金属 原子具有很强的相互作用, 过渡金属在酸性溶液中也不容易被腐蚀, 从而大大提高了催化剂的稳定性.

本综述以 FePt, CoPt和PbPt为例, 总结了它们的相变规律和条件, 同时关注它们的合成-结构-性能的构效关系, 突出金 属间结构在提高活性和稳定性方面的优势. 最后, 为了进一步提高MPt金属间纳米晶的活性, 我们提出一些可能的方向和 观点, 包括: (1) 在实现无序-相变的同时实现形貌调控来提高催化剂活性; (2) 关注尺寸效应, 尽可能减小MPt金属间纳米 晶的尺寸, 提高铂的利用率, 从而提高催化剂活性; (3) 关注材料的有序程度, 尽可能提高材料的有序度, 充分发挥金属间纳 米晶对于氧还原反应的优势.

关键词: 电催化; 氧气还原反应; 纳米晶; 金属间相; 合金

收稿日期: 2017-11-29. 接受日期: 2017-12-23. 出版日期: 2018-04-05.

*通讯联系人. 电话: 18707120529; 传真: (027)87546587; 电子信箱: qing_li@hust.edu.cn

基金来源：国家“千人计划”; 国家自然科学基金(21603078); 国家重点研发计划“材料基因工程关键技术与支撑平台”专项 (2016YFB0700600).

本文的电子版全文由Elsevier出版社在ScienceDirect上出版(http://www.sciencedirect.com/science/journal/18722067). 